\title{
ANALISIS PENGARUH PENGGUNAAN MULTIMEDIA PADA BUDAYA LITERASI PESERTA DIDIK
}

\author{
Megie Yuliyanti \\ Fakultas Ilmu Pendidikan, Universitas Negeri Yogyakarta \\ e-mail : megieyuliyanti.2020@student.uny.ac.id
}

\begin{abstract}
Abstrak
Pandemi Covid-19 membuat dunia pendidikan mengalami perubahan yang sangat signifikan, dari perubahan cara belajar peserta didik hingga perubahan sarana dan prasana yang digunakan dalam proses pembelajaran. Masalah yang paling menonjol yakni rendahnya minat literasi peserta didik, karena mereka telah terpengaruh dan mempunyai ketergantungan yang tinggi terhadap kecanggihan teknologi masa kini yaitu kecanggihan gadget. Menyikapi hal ini peran pendidik, teknolog pendidikan sangat dibutuhkan untuk membuat sebuah inovasi-inovasi pembelajaran, seperti pembuatan media pembelajaran yang kreatif, membuat model maupun strategi pembelajaran yang menyenangkan bagi peserta didik. Sehingga, peserta didik akan tergerak untuk membangun sebuah budaya literasi yang kuat dalam diri mereka. Salah satu teknologi yang dapat diandalkan dalam kondisi pandemi ini, adalah pemanfaatan teknologi multimedia. Oleh karena itu, penelitian ini bertujuan untuk mengetahui seberapa berpengaruhnya penggunaan multimedia untuk meningkatkan budaya literasi peserta didik di masa pandemi. Penelitian ini menggunakan metode deskriptif kualitatif, jenis library reaserch. Sumber data diambil dari beberapa jurnal penelitian yang berkaitan dengan topik pembahasan. Hasil penelitian ini, menunjukkan bahwa produk pengembangan dari media pembelajaran interaktif yang berbasis multimedia sangat efektif untuk meningkatkan kualitas belajar peserta didik, dalam hal peningkatan kemampuan literasi, kecerdasan maupun kognitif mereka. Hasil penelitian ini, secara umum ditinjau dari hasil validasi beberapa ahli materi dan ahli media dengan menggunakan beberapa kategori penilaian dari masing-masing jurnal penelitian. Sehingga, hasil yang diberikan akurat dan terpecaya.
\end{abstract}

Kata Kunci : Multimedia, Budaya Literasi, Covid-19

\section{ANALYSIS OF THE EFFECT OF THE USE OF MULTIMEDIA ON THE LITERATURE CULTURE OF STUDENTS}

\begin{abstract}
The Covid-19 pandemic has made the world of education experience very significant changes, from changes in the way students learn to changes in tools and facilities and infrastructure used in the learning process. The most prominent problem is the low literacy interest of student, because the have been affected and have a high dependence on today's technological sophistication, namely gadgets. In response to this, the role of educators, educational technologists is needed to make learning innovations, such as making creative learning media, making models and learning strategies that are fun for students. Thus, students will be moved to build a strong literacy culture within themselves. One technology that can be relied upon in this pandemic condition is the use of multimedia technology. Therefore, this study aims to determine how influential the use of multimedia is to improve the literacy culture of students during the pandemic. This study uses a qualitative descriptive method, the type of library research. Sources of data are taken from several research journals related to the topic of discussion. The results of this study indicate that the product development of multimedia-based interactive learning media is very effective in improving the learning quality of students, in terms of increasing their literacy, intelligence and cognitive abilities. The results of this study, in general, are viewed from the validation results of several material experts and media experts using several categories of assessment from each research journal. Thus, the results provided are accurate and reliable.
\end{abstract}

Keywords : Multimedia, Literacy Culture, Covid-19

PENDAHULUAN 
Pendidikan adalah salah satu komponen yang menjadi tolak ukur dari berkembang atau tidaknya suatu negara. Pendidikan memegang peranan penting dalam membentuk pribadi peserta didik, sehingga perlu adanya inovasi baru yang dapat mewujudkan kepentingan tersebut. Tetapi di kondisi pandemi Covid-19 saat ini, menyebabkan Indonesia mengalami banyak perubahan di berbagai bidang, terutama di bidang pendidikan. Berdasarkan data statistik Satgas Penanganan Covid-19 pada hari Minggu 4 April 2021 yang dikutip dari laman (Kompas.com,2021), dilaporkan ada 6.731 kasus baru Covid-19. Sehingga, sejak Maret 2020 total kasus Covid-19 sudah ada 1.534.255 yang ditemukan di 34 provinsi pada 510 kabupaten/kota di Indonesia.

Upaya memutus penyebaran virus Covid-19 dapat dilakukan dengan cara pemberian vaksin, physical distancing, dan mematuhi protokol kesehatan. Namun, kebijakan-kebijakan tersebut menghambat laju pertumbuhan di bidang pendidikan, seperti meliburkan peserta didik dan mengubah proses pembelajaran yang berawal dari tatap muka (luring) menjadi Work From Home (WFH). Work From Home (WFH) artinya semua kegiatan belajar maupun mengajar dilakukan di rumah, dengan bantuan teknologi informasi sebagai alat perantaranya. Sebagaimana, kebijakan WFH yang tertuang dalam Surat Edaran Menteri Pendayagunaan Aparatur Negara dan Reformasi Birokrasi Nomor 50/2020 tentang Perubahan Kedua atas Surat Edaran Menteri PAN \& RB Nomor 19/2020 tentang Penyesuaian Sistem Keja Aparatur Sipil Negara dalam Upaya Pencegahan Penyebaran Covid-19 di Lingkungan Instansi Pemerintah. Kebijakan ini, menyebabkan teknolog pendidikan harus berpikir keras untuk mencari solusi yang tepat, dalam membuat media dan model pembelajaran seperti apa yang tepat digunakan untuk peserta didik.

Apalagi, ditambah dengan masalah rendahnya budaya literasi Indonesia yang sudah mendarah-daging di dunia pendidikan. Berdasarkan Programme for International Student Assessment (PISA) yang ditulis pada laman (Kemendagri, 2021), menyatakan bahwa Indonesia menempati peringkat 62 dari 70 negara yang merupakan bagian dari negara literasi. Rendahnya literasi di Indonesia diduga karena rendahnya kualitas pendidik, rendahnya pemanfaatan media pembelajaran, dan disparitas mutu pendidikan. Hal ini, akan berdampak pada kualitas belajar peserta didik, dan dapat merebaknya berita hoaks di lingkungan masyarakat.

Pemanfaatan multimedia sebagai bentuk media pembelajaran interaktif di sekolah adalah salah satu solusi terbaik untuk meningkatkan kualitas budaya literasi peserta didik di masa pandemi. Kenapa multimedia dapat menjadi solusi untuk masalah ini? Karena, konsep multimedia menyajikan informasi berupa teks, audio, gambar, grafik, dan video (M. Suyanto, 2005). Konsep pembelajaran multimedia yang di kemas secara konkrit dengan tampilan yang visual dan interaktif, dinilai dapat membantu dalam hal menarik minat peserta didik untuk belajar. Multimedia pembelajaran diartikan sebagai media penyalur pesan, merangsang pikiran, perasaan, perhatian, sehingga dapat mendorong motivasi belajar peserta didik. Multimedia memiliki potensi besar untuk mengubah dan mengembangkan cara belajar dan teknik belajar peserta didik. Dengan demikian, pengembangan multimedia sebagai media pembelajaran perlu didukung dan harus direalisasikan oleh pendidik maupun stakeldolder lainnya, terlebih lagi ketersediaan dukungan dari teknologi saat ini.

Masuknya peran multimedia di dalam proses belajar dan mengajar, dapat menciptakan suasana yang berbeda dan menyenangkan bagi peserta didik. Karena, multimedia menggabungkan berbagai unsur media, sehingga proses pembelajaran terasa akan lebih menarik. Menurut (Warsita 2008) multimedia interaktif dapat didefinisikan sebagai kombinasi dari berbagai media yang dikemas secara terpadu dan interaktif untuk menyampaikan pesan pembelajaran tertentu.

Disamping itu, proses pembelajaran interaktif atau multimedia tentu sangat membutuhkan peran peserta didik yang aktif, pendidik yang berkompeten, fasilitas yang memadai dan faktor lingkungan yang mendukung. Oleh sebab itu, kita sebagai penggerak pendidikan hendaknya bekerjasama untuk memajukan pendidikan di Indonesia. Jika hal ini dapat terlaksana dengan baik, maka proses pembelajaran dapat berjalan dengan lancar dan dapat menciptakan hasil belajar yang maksimal. Karena, suatu negara dapat dikatakan maju jika pendidikan di negara tersebut juga maju. 
Terkait dengan kebijakan Pemerintah tentang penerapan pembelajaran daring, penulis ingin mengkaji lebih dalam mengenai apa saja pemanfaatan atau produk multimedia yang dapat digunakan untuk meningkatkan budaya literasi peserta didik di masa pandemi Covid19. Oleh karena itu, jurnal ini akan membahas berbagai produk pengembangan multimedia yang dapat menunjang keefektivitasan proses pembelajaran dalam hal meningkatkan budaya literasi pada masa pandemi.

\section{METODE}

Metode yang akan digunakan dalam penelitian ini adalah deskriptif kualitatif, dengan menggunakan jenis library reaserch. Penulis pada awalnya, akan menggunakan metode kualitatif untuk mengambil beberapa data dari jurnal penelitian yang terkait dengan topik permasalahan. Dalam penelitian ini, penulis berhadapan langsung dengan data, yang artinya peneliti tidak berhadapan langsung dengan narasumber maupun terjun ke lapangan. Langkah selanjutnya, penulis menggunakan metode deskriptif yang artinya data-data yang telah diambil akan dideskripsikan dan dikaitkan dengan fenomena yang diangkat yaitu fenomena rendahnya budaya literasi dan Covid19.

\section{HASIL DAN PEMBAHASAN Hasil}

Multimedia merupakan salah satu media pembelajaran interaktif yang penyajian informasinya berupa teks, audio, gambar, grafik, dan video (M. Suyanto, 2005). Pengembangan media pembelajaran interaktif seperti multimedia ini, sudah banyak dilakukan oleh para penggerak pendidikan. Salah satunya, pengembangan model, maupun media pembelajaran untuk masalah budaya literasi. Jika, dilihat dari masalah tersebut budaya literasi Indonesia perlu di tingkatkan. Karena menurut survey penelitian PISA (Kemendagri, 2021) menyatakan bahwa Indonesia menempati urutan 10 negara terendah pada tahun 2021. Minat budaya literasi perlu dibangun dari peserta didik, sehingga budaya literasi nantinya akan mendarah-daging dan menjadi kebiasaan yang positif bagi masyarakat Indonesia.

Seperti yang telah penulis katakan, bahwa penelitian ini mengambil beberapa sampel dari hasil penelitian lain, yang kemudian Penulis kaji lebih lanjut berdasarkan topik yang ia angkat. Penelitian tersebut antara lain :

1. Berdasarkan Penelitian 1 (Gogahu \& Prasetyo, 2020) yang meneliti tentang pengembangan media pembelajaran interaktif berbasis E-Bookstory, menghasilkan data yang dirangkum di dalam Tabel 1, Tabel 2, dan Tabel 3 sebagai berikut :

Tabel 1. Hasil Validasi Pakar Materi

\begin{tabular}{|c|c|c|}
\hline Aspek & Indikator & $\begin{array}{l}\text { Skor } \\
(\%)\end{array}$ \\
\hline \multirow{8}{*}{$\begin{array}{c}\text { Materi } \\
\text { Pembelajaran }\end{array}$} & $\begin{array}{l}\text { Kesesuaian } \\
\text { dengan KD } 2013\end{array}$ & 4 \\
\hline & $\begin{array}{l}\text { Kesesuaian indikator } \\
\text { dengan KD }\end{array}$ & 4 \\
\hline & $\begin{array}{l}\text { Kesesuaian tujuan } \\
\text { pembelajaran }\end{array}$ & 3 \\
\hline & $\begin{array}{l}\text { Kesesuaian judul } \\
\text { dengan isi materi } \\
\text { pelajaran }\end{array}$ & 5 \\
\hline & Kelengkapan materi & 5 \\
\hline & Kejelasan bahasa & 4 \\
\hline & 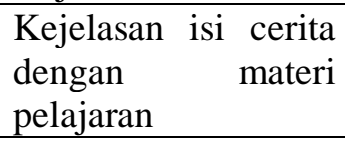 & 4 \\
\hline & $\begin{array}{l}\text { Kesesuaian ilustrasi } \\
\text { cerita dengan materi } \\
\text { pelajaran }\end{array}$ & 4 \\
\hline \multirow{4}{*}{ Bahasa } & Keefektifan kalimat & 4 \\
\hline & Kebakuan istilah & 4 \\
\hline & $\begin{array}{l}\text { Ketepatan peletakan } \\
\text { tanda baca }\end{array}$ & 4 \\
\hline & $\begin{array}{l}\text { Kesesuaian tingkat } \\
\text { perkembangan } \\
\text { emosional peserta } \\
\text { didik }\end{array}$ & 4 \\
\hline \multicolumn{2}{|l|}{ Jumlah } & 49 \\
\hline \multicolumn{2}{|l|}{ Persentase } & 82 \\
\hline
\end{tabular}

Tabel 2. Hasil Validasi Pakar Media 1

\begin{tabular}{|c|l|c|}
\hline Aspek & \multicolumn{1}{|c|}{ Indikator } & $\begin{array}{c}\text { Skor } \\
(\%)\end{array}$ \\
\hline \multirow{5}{*}{ Tampilan } & $\begin{array}{l}\text { Kesesuaian jenis, dan } \\
\text { ukuran huruf }\end{array}$ & 4 \\
\cline { 2 - 3 } & $\begin{array}{l}\text { Kesesuaian ilustrasi } \\
\text { gambar dengan cerita }\end{array}$ & 4 \\
\cline { 2 - 3 } & $\begin{array}{l}\text { Kesesuaian latar } \\
\text { pemilihan } \\
\text { belakang } \\
\text { (background) } \\
\text { disetiap halaman }\end{array}$ & 3 \\
\hline
\end{tabular}




\begin{tabular}{|c|c|c|}
\hline & $\begin{array}{l}\text { Kesesuaian teks } \\
\text { dengan pemilihan } \\
\text { warna }\end{array}$ & 5 \\
\hline & $\begin{array}{ll}\text { Kesesuaian } & \text { teks } \\
\text { dengan gambar }\end{array}$ & 5 \\
\hline \multirow{3}{*}{ Isi Cerita } & $\begin{array}{l}\text { Kesesuaian media E- } \\
\text { Bookstory dengan } \\
\text { materi pembelajaran }\end{array}$ & 4 \\
\hline & $\begin{array}{l}\text { Kebermanfaatan E- } \\
\text { Bookstory dalam } \\
\text { mempermudah } \\
\text { pemahaman konsep }\end{array}$ & 4 \\
\hline & $\begin{array}{l}\text { Kebermanfaatan E- } \\
\text { Bookstory dalam } \\
\text { meningkatkan minat } \\
\text { membaca peserta } \\
\text { didik }\end{array}$ & 4 \\
\hline \multirow[b]{3}{*}{ Bahasa } & $\begin{array}{l}\text { Keefektifan kalimat } \\
\text { dalam E-Bookstory }\end{array}$ & 2 \\
\hline & Kebakuan istilah & 3 \\
\hline & $\begin{array}{l}\text { Kesesuaian tingkat } \\
\text { perkembangan } \\
\text { emosional peserta } \\
\text { didik }\end{array}$ & 4 \\
\hline \multirow{3}{*}{$\begin{array}{l}\text { Kepraktisan } \\
\text { Dalam } \\
\text { Penggunaan }\end{array}$} & $\begin{array}{l}\text { Kejelasan petunjuk } \\
\text { penggunaan } \\
\text { Bookstory }\end{array}$ & 3 \\
\hline & $\begin{array}{l}\text { Tingkat kemudahan } \\
\text { mengakses } \\
\text { Bookstory }\end{array}$ & 4 \\
\hline & $\begin{array}{l}\text { Tingkat kemudahan } \\
\text { penggunaan } \\
\text { Bookstory }\end{array}$ & 4 \\
\hline \multicolumn{2}{|l|}{ Jumlah } & 47 \\
\hline \multicolumn{2}{|l|}{ Persentase } & 67 \\
\hline
\end{tabular}

Tabel 3. Hasil Validasi Pakar Media 3

\begin{tabular}{|c|l|c|}
\hline Aspek & \multicolumn{1}{|c|}{ Indikator } & $\begin{array}{c}\text { Skor } \\
(\%)\end{array}$ \\
\hline \multirow{5}{*}{ Tampilan } & $\begin{array}{l}\text { Kesesuaian jenis, dan } \\
\text { ukuran huruf }\end{array}$ & 3 \\
\cline { 2 - 3 } & $\begin{array}{l}\text { Kesesuaian ilustrasi } \\
\text { gambar dengan cerita }\end{array}$ & 3 \\
\cline { 2 - 3 } & $\begin{array}{l}\text { Kesesuaian latar } \\
\text { pemilihan } \\
\text { belakang disetiap } \\
\text { background) } \\
\text { halaman dian }\end{array}$ & 3 \\
\cline { 2 - 3 } & $\begin{array}{l}\text { Kesesuaian teks } \\
\text { dengan pemilihan } \\
\text { warna }\end{array}$ & 3 \\
\cline { 2 - 3 } & $\begin{array}{l}\text { Kesesuaian teks } \\
\text { dengan gambar }\end{array}$ \\
\hline
\end{tabular}

\begin{tabular}{|c|c|c|}
\hline \multirow{3}{*}{ Isi Cerita } & $\begin{array}{lr}\text { Kesesuaian } & \text { E- } \\
\text { Bookstory dengan } \\
\text { materi pembelajaran }\end{array}$ & 4 \\
\hline & $\begin{array}{l}\text { Kebermanfaatan E- } \\
\text { Bookstory dalam } \\
\text { mempermudah } \\
\text { pemahaman konsep }\end{array}$ & 3 \\
\hline & $\begin{array}{lr}\text { Kebermanfaatan E- } \\
\text { Bookstory dalam } \\
\text { meningkatkan minat } \\
\text { membaca peserta } \\
\text { didik }\end{array}$ & 3 \\
\hline \multirow{3}{*}{ Bahasa } & $\begin{array}{l}\text { Keefektifan kalimat } \\
\text { dalam media E- } \\
\text { Bookstory }\end{array}$ & 3 \\
\hline & Kebakuan istilah & 3 \\
\hline & $\begin{array}{l}\text { Kesesuaian tingkat } \\
\text { perkembangan } \\
\text { emosional peserta } \\
\text { didik }\end{array}$ & 3 \\
\hline \multirow{3}{*}{$\begin{array}{l}\text { Kepraktisan } \\
\text { Dalam } \\
\text { Penggunaan }\end{array}$} & $\begin{array}{lr}\text { Kejelasan petunjuk } \\
\text { penggunaan } \\
\text { Bookstory }\end{array}$ & 3 \\
\hline & $\begin{array}{l}\text { Tingkat kemudahan } \\
\text { mengakses } \\
\text { Bookstory }\end{array}$ & 3 \\
\hline & $\begin{array}{l}\text { Tingkat kemudahan } \\
\text { penggunaan } \\
\text { Bookstory }\end{array}$ & 3 \\
\hline \multicolumn{2}{|l|}{ Jumlah } & 43 \\
\hline \multicolumn{2}{|l|}{ Persentase } & 61 \\
\hline
\end{tabular}

Dari Tabel 1, 2, 3 dapat disimpulkan bahwa validasi materi mancapai angka $82 \%$, sedangkan untuk hasil validasi media 1 dan media 2 secara berurutan $67 \%$ dan $61 \%$. Hasil tersebut, berdasarkan validasi dari 3 orang dosen ahli yaitu 1 dosen ahli materi dan 2 dosen ahli media. Persentase tersebut dapat disimpulkan bahwa media pembelajaran berbasis multimedia ini dikatakan layak dan dapat digunakan untuk menunjang keefektifitasan pembelajaran literasi anak.

2. Berdasarkan Penelitian 2 (Harianto et al., 2019) yang menggunakan metode research and development, yang mengkaji tentang pengembangan media pembelajaran kimia berbasis android untuk menumbuhkan literasi sains peserta didik pada materi reaksi redoks dan elektrokimia, menghasilkan beberapa data yakni :

a) Validasi media diperoleh persentase kelayakan sebesar $80 \%$ dengan kriteria sangat layak. Validasi media meliputi, 
aspek tampilan, penyajian dan pemrograman.

b) Validasi praktisi diperoleh $82,22 \%$ yang meliputi aspek cover, isi materi, pembelajaran, kebahasaan, penyajian dan tampilan.

c) Rata-rata hasil tes kompetensi literasi sains pre-test sebesar 20,27 dan nilai post-test rata-rata sebesar 74,16 serta nilai $\mathrm{N}$-gain sebesar 0,65 yaitu sedang.

3. Berdasarkan Penelitian 3 (Ramdani et al., 2020) yang meneliti tentang pengembangan media pembelajaran interaktif berbasis android untuk meningkatkan literasi sains peserta didik, menghasilkan data bahwa rata-rata hasil validasi produk sebesar $84 \%$ dengan kriteria sangat layak, yang terdiri dari penilaian dari perangkat Silabus, RPP, Media, dan Instrumen. Hasil penilaian tersebut, yang dinilai oleh 3 ahli validator dengan mempertimbangkan aspek isi, penyajian, dan kegiatan pembelajaran.

Dari data diatas, dapat disimpulkan bahwa media pembelajaran kimia yang berbasis android dapat menumbuhkan literasi peserta didik. Di dalam media pembelajaran interaktif tersebut, peserta didik diberikan kesempatan untuk melatih mengembangkan cara berpikir, bersikap ilmiah, sehingga peserta didik dapat mengimplementasikan pengetahuan yang dimiliki ke dalam kehidupan sehari-hari. Penggunaan media pembelajaran interaktif ini juga, sangat praktis di dalam penggunaannya. Selain itu, di dalamnya terdapat berbagai fiturfitur menarik yang di desain untuk menarik minat baca peserta didik. Sehingga, tujuan dari meningkatan literasi peserta didik pun dapat dicapai secara maksimal.

\section{Pembahasan}

Kemampuan literasi merupakan kemampuan dasar yang harus dimiliki oleh peserta didik sejak dini. Membangun literasi peserta didik dapat diawali dari lingkungan keluarga dan lingkungan sekolah. Oleh karena itu, setiap orang tua perlu menyadari urgensi budaya literasi kepada anak mereka sejak dini. Tetapi nampaknya hal ini tidak berjalan dengan mestinya, karena menurut data survey penelitian dari Programme for International Student Assessment (PISA) yang ditulis pada laman (Kemendagri, 2021) menyatakan bahwa Indonesia menempati peringkat 62 dari 70 negara yang merupakan bagian dari negara literasi. Rendahnya literasi di Indonesia diduga karena rendahnya kualitas pendidik, rendahnya pemanfaatan media pembelajaran, dan disparitas mutu pendidikan. Hal ini, akan berdampak pada kualitas belajar peserta didik, dan dapat merebaknya berita hoaks di lingkungan masyarakat.

Sedangkan di era digitalisasi seperti saat ini, teknologi telah berkembang sangat pesat dan seharusnya fenomena ini dapat dimanfaatkan dengan baik oleh teknolog pendidikan dan pendidik, untuk membuat sebuah inovasi media pembelajaran yang tepat guna meningkatkan kemampuan literasi peserta didik di Indonesia. Multimedia atau media pembelajaran interaktif, sangat disarankan untuk memecahkan masalah literasi di Indonesia saat ini. Karena, masalah literasi ini sebagian besar disebabkan oleh menurunnya tingkat motivasi belajar peserta didik untuk membaca. Sedangkan, di dalam multimedia terdapat berbagai komponen audio, video, gambar, grafik, maupun animasi yang dapat memacu dan meningkatkan motivasi belajar peserta didik.

Media merupakan alat untuk menyalurkan sebuah informasi kepada orang lain. Sedangkan, jika dikaitkan dengan pembelajaran ialah sarana yang digunakan oleh pendidik untuk menyampaikan sebuah informasi berupa materi pelajaran ataupun pesan pendidikan kepada peserta didik. Menurut Breidle dan Rossi dalam (Gogahu \& Prasetyo, 2020) mengatakan bahwa media pembelajaran merupakan semua alat dan bahan yang dapat digunakan untuk mencapai sebuah tujuan pendidikan, media tersebut berupa radio, televisi, buku, koran, majalah, dan sebagainya. Sedangkan, menurut Yaumi dalam (Gogahu \& Prasetyo, 2020) mengatakan media pembelajaran merupakan peralatan yang menyediakan lingkungan belajar dengan dorongan atau rangsangan, alat tersebut berupa video, teks, benda nyata, dan multimedia. Sehingga, penulis menyimpulkan bahwa media pembelajaran merupakan alat yang dapat digunakan untuk menyalurkan informasi dari guru kepada peserta didik untuk tujuan pendidikan, yang berguna untuk menarik minat maupun motivasi belajar mereka.

Pembuatan media pembelajaran interaktif atau multimedia tidak terlepas dari peran aplikasi pembuatannya. Contoh aplikasi yang dapat membuat sebuah media pembelajaran interaktif antara lain, Adobe Flash/Adobe Animate, Adobe Ilustrator, Adobe 
Dreamweaver, Microsoft Power Point, dan lain sebagainya. Sedangkan contoh aplikasi media pembelajaran interaktif, antara lain seperti RuangGuru, KelasKita, Quipper, dan lainya sebagainya. Dari berbagai contoh aplikasiaplikasi ini, dapat dibuktikan bahwa teknologi digital sangat terikat pada dunia pendidikan dan peran multimedia disini juga sangat dibutuhkan. Selain untuk menarik minat belajar peserta didik, multimedia juga dibutuhkan untuk meningkatkan kualitas pendidikan di Indonesia, dari segi pengelolaan pembelajaran di dalam pembuatan strategi pembelajaran, media pembelajaran, dan dari segi meningkatkan kualitas atau kompetensi dari pendidik itu sendiri.

Oleh sebab itu, di dalam penelitian ini penulis ingin mengkaji lebih lanjut mengenai seberapa efektivitasnya media pembelajaran interaktif jika diterapkan kepada peserta didik guna meningkatkan motivasi belajar mereka dalam hal literasi. Penulis mengkaji setidaknya ada 3 jurnal ilmiah mengenai peran multimedia di dalam meningkatkan literasi peserta didik. Penelitian tersebut dirangkum dalam Penelitian 1, Penelitian 2 dan Penelitian 3.

Berdasarkan Penelitian 1, dilatarbelakangi oleh ketertarikan peneliti untuk mengembangkan media pembelajaran interaktif yang bernama E-Bookstory dengan menggunakan konsep multimedia, untuk meningkatkan literasi peserta didik. Menurut (Gogahu \& Prasetyo, 2020) tujuan penggunaan E-Bookstory ada 3 yaitu : 1) sebagai sarana pembelajaran, 2) mempermudah pendidik dan peserta didik dalam proses pembelajaran, 3) memudahkan pendidik dalam pemberian materi, karena media tersebut bersifat fleksibel. Setelah penulis menganalisis lebih lanjut, manfaat media pembelajaran ini antara lain : 1) motivasi belajar membaca peserta didik dapat meningkat, 2) dapat menumbuhkan kepercayaan diri di dalam peserta didik, 3) suasana belajar menjadi menyenangkan, 4) dapat mendorong peserta didik untuk menyukai cerita dengan cerita yang berbeda, 5) menumbuhkan kebiasaan membaca.

Kelebihan dari menggunakan EBookstory antara lain : 1) mudah diakses oleh peserta didik, 2) biaya yang relatif terjangkau, 3) fleksibel, dapat dibawa kemanapun, 4) anti rusak, 5) dan dapat menghemat waktu. Sedangkan, kekurangannya antara lain : 1) diperlukan kapasitas penyimpanan yang cukup besar pada perangkat elektronik untuk menyimpan file, 2) tidak semua perangkat elektronik dapat mengakses E-Bookstory, 3) penggunaan E-Bookstory hanya dapat digunakan melalui Handphone, Laptop, Komputer, 4) format security ebook seketika dapat di retas.

Di dalam pembuatan desain media EBookstory, peneliti mengaitkan muatan pembelajaran Bahasa Indonesia dengan pelajaran IPA yang disusun menjadi cerita nonfiksi sesuai dengan kehidupan sehari-hari, sehingga dapat dipahami oleh peserta didik pada tingkat Sekolah Dasar. E-Bookstory berbentuk buku cerita digital yang mengedepankan multimedia, yang di dalamnya berisi Identitas Pembuat, Petunjuk, KI/KD, Isi Materi, Evaluasi, Komentar, Glosarium, dan Daftar Pustaka. Di dalam perancangan media E-Bookstory ini, peneliti menggunakan aplikasi Adobe Ilustrator. Karena, aplikasi ini dirasa mempunyai fitur-fitur yang kompleks untuk membuat sebuah media pembelajaran interaktif.

Pada tahap pengujian pada produk media pembelajaran interaktif E-Bookstory, peneliti menggunakan validasi dari 3 dosen ahli, yaitu 1 dosen ahli materi dan 2 dosen ahli media. Pada tahap validasi materi yang terdiri aspek materi pembelajaran dan bahasa, menghasilkan skor 49 dengan persentase $82 \%$ yang dikategorikan sangat tinggi dan layak untuk digunakan. Sedangkan, pada tahap validasi media 1 dan media 2 yang terdiri dari aspek tampilan, isi cerita, bahasa, dan kepraktisan dalam penggunaan memperoleh skor secara berurutan 47 dan 43 dengan persentase $67 \%$ dan $61 \%$, dengan hasil tersebut dikategorikan tinggi dan layak digunakan. Sehingga, dapat disimpulkan bahwa media pembelajaran interaktif yang bernama EBookstory sangat layak dan efektif digunakan untuk peserta didik, untuk menunjang kualitas belajar dalam hal meningkatkan kemampuan literasi mereka.

Berdasarkan Penelitian 2, pengembangan media pembelajaran interaktif yang berbasis android memiliki beberapa karakteristik antara lain : 1) berbentuk aplikasi android, 2) dapat diakses menggunakan bantuan aplikasi lain yaitu Adobe Flash Professional CS6 dengan action script 3 versi android, 3) di desain untuk peserta didik kelas XII SMA/MA yang berdasarkan pada Kurikulum Tingkat Satuan Pendidikan (KTSP). Peneliti menguji kelayakan media 
pembelajaran ini, mengacu pada hasil validasi ahli materi dan ahli media. Berdasarkan hasil validasi tersebut, dapat disimpulkan bahwa : 1) validasi materi memperoleh skor $80 \%$ dengan kategori sangat layak, yang diuji menggunakan skala besar yaitu sebagai media pembelajaran di sekolah, 2) validasi media memperoleh skor $80 \%$ dengan kategori sangat layak, yang diuji menggunakan skala besar.

Media pembelajaran interaktif ini, bersifat fleksibel karena bentuknya yang berupa digital yang dapat digunakan kapanpun, dimanapun, dan dapat digunakan secara berulang-ulang. Hasil validasi praktisi yaitu guru dan mahasiswa secara berurutan mencapai angka $82,22 \%$ dan $86,35 \%$ dengan kategori sangat layak. Dari hasil validasi tersebut, dapat disimpulkan bahwa media pembelajaran interaktif yang berbasis android sangat praktis dan sangat ccok digunakan di dalam proses pembelajaran di sekolah.

Sedangkan, untuk pengujian nilai keefektivitasan media pembelajaran interaktif kimia yang berbasis android ini menggunakan uji coba $\mathrm{N}$-gain. Hal ini, dimasudkan untuk mengetahui pertumbuhan literasi sains peserta didik itu seperti apa. Pada uji coba N-gain, peserta didik diberi soal pre-test dan post-test berupa soal pilihan ganda yang beralasan sejumlah 10 butir pertanyaan. Uji coba soal pretest dan post-test, menghasilkan skor rata-rata peserta didik secara berurutan 20,27 dan 74,16. Kemudian dari hasil skor tersebut, peneliti melakukan perhitungan nilai $\mathrm{N}$-gain yaitu sebesar 0,65 dengan kategori sedang. Sehingga, dari data tersebut dapat disimpulkan bahwa media pembelajaran interaktif kimia yang berbasis android dapat meningkatkan kualitas belajar peserta didik dalam hal meningkatkan kemampuan literasi mereka.

Berdasarkan Penelitian 3 (Ramdani et al., 2020), difokuskan pada tahap pengembangan yaitu uji validasi. Pada tahap pengembangan ini, peneliti terlebih dahulu melalui tahap defined dan design. Tahap defined antara lain analisis isi materi dan tinjauan pustaka. Setelah itu, dilakukan tahap perancangan yaitu penyiapan perangkat prototipe, seperti persiapan tes, pemilihan media, dan pemilihan format. Pada tahap desain, peneliti menyusun produk media pembelajaran interaktif dengan membuat flowchart dan storyboard. Flowchart dan soryboard ini, digunakan sebagai panduan untuk proses pengerjaan produk tersebut.
Setelah bahan terkumpul seperti gambar, video, dan animasi, selanjutnya masuk ke dalam proses pembuatan media pembelajaran dengan menggunakan aplikasi Adobe Flash CS 6. Produk media pembelajaran ini, berupa aplikasi android yang betujuan untuk membantu pendidik dalam menyampaikan materi pembelajaran dan juga sebagai sumber belajar untuk peserta didik yang dapat digunakan dimanapun, dan kapanpun.

Kelebihan dari media pembelajaran interaktif ini, sebagai berikut : 1) produk dikemas dalam sebuah Compact Dist (CD), 2) dilengkapi oleh fitur petunjuk untuk memudahkan peserta didik untuk memahami produk yang dikembangkan oleh peneliti, 3) dilengkapi oleh fitur pembahasan dan fitu evaluasi yang memungkin peserta didik untuk melihat hasil yang mereka capai.

Dari penelitian-penelitian diatas, jika keefektivitasan peran multimedia dikaitkan dengan fenomena Covid-19 saat ini yang membuat proses pembelajaran dilakukan secara daring, dinilai sangat cocok untuk digunakan di dalam proses pembelajaran. Karena, media pembelajaran tersebut memiliki sifat fleksibilitas yang dapat digunakan dimana saja, kapan saja, dan dapat diputar berulang-ulang. Segi perancangan desain juga sangat berpengaruh pada nilai keefektivitasan sebuah produk media pembelajaran interaktif. Karena, hal tersebut dapat mempengaruhi pemahaman, motivasi, dan cara berpikir peserta didik. Contoh dari desain produk media pembelajaran interaktif yang baik yaitu dapat dilihat dari desain yang dirancang oleh para peneliti seperti fitur-fitur yang dibuat menarik, animasi yang digunakan bervariatif, kualitas grafik yang tinggi, penggunaan efek yang tepat dan isi materi menarik. Sehingga, peserta didik akan mudah memahami materi yang diajarkan, dapat menambah motivasi belajar karena desain yang menarik, serta dapat meningkatkan prestasi belajar dari segi kecerdasan dan kognitif peserta didik dalam hal literasi.

\section{PENUTUP}

Indonesia menempati peringkat 62 dari 70 negara yang merupakan bagian dari negara literasi, hal ini menandakan bahwa tingkat literasi di Indonesia sangat rendah. Oleh karena itu, diperlukan inovasi-inovasi baru untuk pendidikan. Salah satunya adalah dengan mengembangkan media pembelajaran yang berbasis multimedia. Karena, multimedia 
merupakan sebuah media yang di dalamnya terdapat banyak media yang membangunnya. Dengan kata lain, jika pengembangan media pembelajaran menggunakan multimedia sebagai salah satu pembentuknya, maka media pembelajaran tersebut akan menarik, efektif, dan efisien dalam meningkatkan budaya literasi di Indonesia.

Pada Penelitian 1, Penelitian 2 dan Penelitian 3, penulis menyimpulkan bahwa produk media pembelajaran interaktif atau multimedia sangat efektif untuk menambah motivasi, kecerdasan maupun kognitif peserta didik dalam hal literasi. Hal ini, dapat dinilai dari segi desain yang dirancang oleh peneliti yaitu fitur-fitur yang dibuat, animasi yang digunakan, kualitas grafik yang tinggi, penggunaan efek yang bervariatif dan dari segi isi materi yang dikemas dengan menarik. Sehingga, peran multimedia sangat dibutuhkan untuk menunjang kualitas pembelajaran jarak jauh bagi peserta didik. Disamping itu pada kondisi Covid-19 saat ini, beberapa peran sangat dibutuhkan yaitu peran dari peserta didik yang aktif, pendidik yang berkompeten, fasilitas yang memadai dan faktor lingkungan yang mendukung.

\section{UCAPAN TERIMA KASIH}

Peneliti mengucapkan terima kasih kepada Dr. Pujiriyanto S.Pd., M.Pd. selaku Dosen Mata Kuliah Penulisan Karya Ilmiah yang telah memberikan ilmu maupun arahan tentang pengerjaan penelitian. Serta peneliti berterimakasih juga kepada orang tua maupun pihak-pihak terkait, yang sudah ikut membantu dalam proses pengerjaan karya ilmiah ini.

\section{DAFTAR PUSTAKA}

Gogahu, D. G. S., \& Prasetyo, T. (2020). Pengembangan Media Pembelajaran Berbasis E-Bookstory untuk Meningkatkan Literasi Membaca Siswa Sekolah Dasar. Jurnal Basicedu, 4(4), 1004-1015.

https://doi.org/10.31004/basicedu.v4i4.49 3

Harianto, A., Suryati, S., \& Khery, Y. (2019). Pengembangan Media Pembelajaran Kimia Berbasis Android Untuk Penumbuhan Literasi Sains Siswa Pada Materi Reaksi Redoks Dan Elektrokimia. Hydrogen: Jurnal Kependidikan Kimia, $5(2)$, 35. https://doi.org/10.33394/hjkk.v5i2.1588
Kemendagri. (2021). Tingkat Literasi Indonesia di Dunia Rendah, Ranking 62 Dari $70 \quad$ Negara. Perpustakaan Kemendagri. https://perpustakaan.kemendagri.go.id/?p $=4661$

Kompas.com. (2021). Aneka Tafsir Data Statistik Corona. https://www.kompas.com/tren/read/2021/ 04/06/133640665/aneka-tafsir-datastatistik-corona

Kuswanto, J., Walusfa, Y., Artikel, S., Korespondensi, A., Ratu Penghulu No, J., Sari, K., Baru, T., Raja Tim, B., Ogan Komering Ulu, K., \& Selatan, S. (2017). Pengembangan Multimedia Pembelajaran pada Mata Pelajaran Teknologi Informasi dan Komunikasi Kelas VIII. Innovative Journal of Curriculum and Educational Technology IJCET, 6(2), 58-64. https://journal.unnes.ac.id/sju/index.php/ ujet

M. Suyanto. (2005). Multimedia: Alat untuk Meningkatkan Keunggulan Bersaing. https://openlibrary.telkomuniversity.ac.id /pustaka/64636/multimedia-alat-untukmeningkatkan-keunggulan-bersaing.html

Ramdani, A., Jufri, A. W., \& Jamaluddin, J. (2020). Pengembangan Media Pembelajaran Berbasis Android pada Masa Pandemi Covid-19 untuk Meningkatkan Literasi Sains Peserta Didik. Jurnal Kependidikan: Jurnal Hasil Penelitian Dan Kajian Kepustakaan Di Bidang Pendidikan, Pengajaran Dan Pembelajaran, 6(3), 433. https://doi.org/10.33394/jk.v6i3.2924 